\title{
FAKTOR YANG BERHUBUNGAN DENGAN PELAKSANAAN KESELAMATAN DAN KESEHATAN KERJA DI RUMAH SAKIT UMUM, KOTA DENPASAR
}

\author{
Kadek Eni Dwiari*, Partha Muliawan \\ Program Studi Kesehatan Masyarakat Fakultas Kedokteran Universitas Udayana \\ *email: sisma.enidwiari@gmail.com
}

\begin{abstract}
ABSTRAK
Rumah sakit merupakan suatu industri jasa dengan berbagai potensi bahaya yang dapat menyebabkan kecelakaan akibat kerja dan penyakit akibat kerja, sehingga diperlukan upaya meminimalisir risiko bahaya di rumah sakit dengan pelaksanaan Keselamatan dan Kesehatan Kerja Rumah Sakit (K3RS). Penelitian ini adalah penelitian analitik dengan rancangan cross-sectional, bertujuan untuk mengetahui faktor yang berhubungan dengan pelaksanaan K3RS. Penelitian dilakukan di satu rumah sakit umum yang terletak di Kota Denpasar pada bulan Maret 2019. Sampel penelitian ini berjumlah 187 responden yang dipilih dengan teknik proportionate stratified random sampling. Pengambilan data dilakukan dengan wawancara menggunakan kuesioner. Hasil penelitian menunjukkan bahwa sebanyak 53,48\% responden mengaku melaksanakan K3RS yang baik. Hasil uji chi-square menunjukkan terdapat hubungan antara jenis kelamin, sikap, kebijakan, kepemimpinan dan ketersediaan sarana prasarana K3RS terhadap pelaksanaan K3RS $(p<0,05)$. Berdasarkan hasil analisis multivariabel, sikap merupakan faktor individu yang paling signifikan berpengaruh terhadap pelaksanaan K3RS responden (adjusted $\mathrm{PR}=1,59 ; 95 \%$ CI 1,11-2,30).
\end{abstract}

Kata Kunci: K3RS, Tenaga kesehatan, Rumah sakit

\begin{abstract}
Hospital is a service industry with various potential hazards which can cause an accident due to work and illness due to work for the health workers. Therefore, efforts are needed to minimize the risk of harm in the hospital with the implementation of hospital occupational health and safety. This study was a analytical study with a cross-sectional design to know factors related to hospital occupational health and safety implementation. The study was conducted at a public hospital in Denpasar city during March 2019. Number of samples in this study involved 187 among 275 health workers chosen by proportionate stratified random sampling. Data were collected by conducting interviews using a questionnaire. The results showed that $53,48 \%$ of health workers have a good implementation of hospital occupational health and safety. The result of chi-square test found that sex, attitude, policy, leadership and the availability of hospital occupational health and safety facilities were the factors related to health workers' implementation of hospital occupational health and safety $(p<0,05)$. A multivariable analysis showed that attitude was the most significant factor related to health workers' implementation of hospital occupational health and safety (adjusted PR=1,59; 95\% CI 1,11-2,30).
\end{abstract}

Key Words: Hospital occupational health and safety, Health workers, Hospital.

\section{PENDAHULUAN}

Rumah sakit merupakan salah satu institusi penyelenggara pelayanan kesehatan di industri jasa yang mempunyai karakteristik khusus seperti padat karya, padat pakar, padat modal, padat teknologi, memiliki akses lebih terbuka bagi bukan pekerja rumah sakit (pasien, pengantar pasien dan pengunjung pasien), serta memiliki kegiatan yang terus menerus setiap hari dengan berbagai potensi bahaya yang terdapat di rumah sakit (Kementerian Kesehatan RI, 2016).

\section{Hasil laporan Nasional Safety} Council (NSC) tahun 2008 menunjukkan 
Vol. 7 No. $2: 35$ - 47

bahwa terjadinya kecelakaan di rumah sakit $41 \%$ lebih besar dari pekerja di industri lain. Kasus yang paling sering terjadi adalah tertusuk jarum, terkilir, sakit pinggang, tergores/terpotong, luka bakar, penyakit infeksi dan lain-lain (Ernawati \& Nurlelawati, 2017). Kasus kecelakaan akibat kerja (KAK) pada tenaga kesehatan di negara Amerika Serikat pada tahun 2011 tercatat sebanyak 58.860 kasus dan penyakit akibat kerja (PAK) juga menyebabkan tenaga kesehatan tidak bekerja (OSHA, 2013). Setiap tahunnya, di Amerika Serikat diperkirakan terjadi 600.000-1.000.000 kasus luka tusuk jarum, namun lebih dari $60 \%$ tidak dilaporkan. Selain itu diketahui sebanyak 5.000 tenaga kesehatan terinfeksi Hepatitis B Virus (HBV) dan 47 positif Human Immunodeficiency Virus (HIV) (Kementerian Kesehatan RI, 2010).

Di Indonesia, data terkait kejadian KAK dan PAK pada tenaga kesehatan belum tercatat dengan baik. Namun penelitian-penelitian di beberapa rumah sakit di Indonesia menyimpulkan kejadian KAK di rumah sakit akibat tertusuk jarum pada tahun 2005-2007 mencapai 38-73\% dari total tenaga kesehatan. Sedangkan kasus PAK seperti low back pain pada tenaga kesehatan sebanyak 83,3\% dari pekerja di instalasi bedah sentral Rumah Sakit Umum Daerah di Jakarta tahun 2006 (Kementerian Kesehatan RI, 2010).

Idealnya risiko KAK dan PAK yang dapat dialami oleh tenaga kesehatan di rumah sakit dapat diminimalisir dengan pelaksanaan keselamatan dan kesehatan kerja rumah sakit (K3RS). Hal ini sesuai dengan Peraturan Menteri
Kesehatan Republik Indonesia Nomor 66 Tahun 2016 tentang K3RS untuk menjamin keselamatan dan kesehatan SDM rumah sakit maupun orang lain yang berkunjung ke rumah sakit (Kementerian Kesehatan, 2016). Penelitian Ernawati \& Nurlelawati (2017) menyatakan bahwa dalam penerapan $\mathrm{K} 3$ pada tenaga kesehatan di RSIA Permata Sarana Husada Tangerang Selatan, terdapat hubungan signifikan antara sikap, motivasi dan penggunaan APD oleh tenaga kesehatan terhadap penerapan K3. Penelitian Ristiono \& Azkha (2010) tentang regulasi dan penerapan Keselamatan dan Kesehatan Kerja (K3) Rumah Sakit di Propinsi Sumatera Utara, menyatakan bahwa penyelengaraan K3RS dipengaruhi oleh regulasi dan kebijakan dari pemerintah, komitmen manajemen rumah sakit dan faktor yang mempengaruhi efektivitas regulasi. Hal ini menunjukkan pelaksanaan K3RS oleh tenaga kesehatan tidak terlepas dari faktor individu maupun faktor organisasi. Di Bali, belum pernah dilakukan penelitian terhadap faktor individu dan organisasi sehingga belum diketahui faktor yang mana berperan terhadap pelaksanaan K3RS.

Berdasarkan latar belakang tersebut penulis ingin mengetahui hubungan faktor individu (umur, jenis kelamin, tingkat pendidikan, pekerjaan, masa kerja, pengetahuan dan sikap) dan faktor organisasi (kebijakan, kepemimpinan, dan ketersediaan sarana prasarana K3RS) terhadap pelaksanaan K3RS. 


\section{METODE PENELITIAN}

Penelitian ini merupakan penelitian analitik dengan menggunakan rancangan cross-sectional, dilaksanakan di salah satu rumah sakit umum di Kota Denpasar selama bulan Maret 2019. Sampel dalam penelitian ini berjumlah 187 responden dari populasi sebanyak 275 tenaga kesehatan serta memenuhi kriteria inklusi yaitu tenaga kesehatan yang telah bekerja minimal 1 tahun serta dalam bekerja melakukan kontak langsung dengan pasien dalam memberikan tindakan/intervensi. Sedangkan kriteria eksklusi yaitu tenaga kesehatan yang menolak menjadi responden. Besar sampel dihitung menggunakan rumus uji hipotesis beda dua proporsi dan dipilih menggunakan teknik proportionate stratified random sampling.

Data dikumpulkan dengan cara wawancara menggunakan kuesioner yang berisi karakteristik demografi, pengetahuan, sikap, kebijakan, kepemimpinan, dan ketersediaan sarana prasarana K3RS. Kuesioner sikap, kebijakan, dan kepemimpinan merupakan kuesioner yang diadaptasi dari penelitian Winarno (2016) serta telah diuji validitas dan reabilitas kuesioner pada penelitian sebelumnya, sedangkan kuesioner untuk mengukur tingkat pengetahuan, sarana prasarana K3RS dan pelaksanaan K3RS merupakan kuesioner yang penulis kembangkan berdasarkan standar pelaksanaan K3RS dari Peraturan Menteri Kesehatan Nomor 66 Tahun 2016 serta telah diuji validitas dan reabilitas kuesioner pada 30 responden.

Pengkategorian variabel dalam penelitian ini berdasarkan median karena distribusi data pada variabel penelitian tidak normal. Data dianalisis secara univariabel yang bertujuan untuk mendeskripsikan karakteristik setiap variabel penelitian ke dalam bentuk distribusi frekuensi dan proporsi. Analisis bivariabel dengan menggunakan chisquare dengan tingkat kepercayaan 95\% $(a=0,05)$ untuk mengetahui hubungan antara dua variabel yaitu satu variabel bebas dan satu variabel tergantung, serta analisis multivariabel digunakan untuk mengetahui hubungan lebih dari satu variabel bebas dengan variabel tergantung. Metode analisis multivariabel dibedakan menurut jenis variabel outcome serta ukuran asosiasi penelitian (Widarsa, dkk. 2016). Pada penelitian ini, jenis variabel outcome yang digunakan merupakan variabel binary serta menggunakan rancangan penelitian crosssectional yang mana ukuran asosiasinya adalah PR sehingga Poisson regression merupakan jenis analisis multivariabel yang digunakan dalam penelitian ini.

\section{HASIL}

Berdasarkan analisis deskriptif pada Tabel 1 menunjukkan bahwa proporsi responden paling banyak berumur 30-39 tahun, mayoritas perempuan, berpendidikan akhir diploma, bekerja sebagai perawat serta memiliki masa kerja 6-10 tahun. Mayoritas responden memiliki pelaksanaan K3RS baik dengan pengetahuan baik dan sikap 
Eni Dwiari \& Partha Muliawan

Vol. 7 No. $2: 35$ - 47

positif terhadap pelaksanaan K3RS. Pada

hasil analisis faktor organisasi menunjukkan bahwa mayoritas

responden memiliki persepsi kebijakan
K3RS, kepemimpinan K3RS, serta ketersediaan sarana dan prasarana K3RS sudah baik.

Tabel 1. Analisis Deskriptif Faktor Individu dan Organisasi

\begin{tabular}{|c|c|c|}
\hline Faktor Individu & Frekuensi (n) & Proporsi (\%) \\
\hline \multicolumn{3}{|l|}{ Umur } \\
\hline 20-29 tahun & 26 & 13.90 \\
\hline 30-39 tahun & 89 & 47.59 \\
\hline 40-49 tahun & 38 & 20.32 \\
\hline$\geq 50$ tahun & 34 & 18.18 \\
\hline \multicolumn{3}{|l|}{ Jenis Kelamin } \\
\hline Laki-laki & 58 & 31.02 \\
\hline Perempuan & 129 & 68.98 \\
\hline \multicolumn{3}{|l|}{ Tingkat Pendidikan } \\
\hline Diploma & 123 & 65.78 \\
\hline Sarjana & 23 & 12.30 \\
\hline Spesialis & 20 & 10.70 \\
\hline Profesi & 21 & 11.23 \\
\hline \multicolumn{3}{|l|}{ Pekerjaan } \\
\hline Dokter & 35 & 18.72 \\
\hline Perawat & 102 & 54.55 \\
\hline Bidan & 33 & 17.65 \\
\hline Tenaga kesehatan lain: & 17 & 9.09 \\
\hline 1. Analis kesehatan & 11 & 5.88 \\
\hline 2. Fisioterapis & 2 & 1.07 \\
\hline 3. Radiografer & 4 & 2.14 \\
\hline \multicolumn{3}{|l|}{ Masa Kerja } \\
\hline 1-5 tahun & 30 & 16.04 \\
\hline 6-10 tahun & 58 & 31.02 \\
\hline 11-15 tahun & 38 & 20.32 \\
\hline 16-20 tahun & 20 & 10.70 \\
\hline 21-25 tahun & 13 & 6.95 \\
\hline 26-30 tahun & 19 & 10.16 \\
\hline$\geq 30$ tahun & 9 & 4.81 \\
\hline \multicolumn{3}{|l|}{ Pengetahuan } \\
\hline Baik & 125 & 66.84 \\
\hline Kurang Baik & 62 & 33.16 \\
\hline Lanjutan Tabel 1. & & \\
\hline
\end{tabular}




\begin{tabular}{lcc}
\hline Faktor Individu & Frekuensi (n) & Proporsi (\%) \\
\hline Sikap & & \\
Positif & 98 & 52.41 \\
Negatif & 89 & 47.59 \\
\hline Faktor Organisasi & &
\end{tabular}

Faktor Organisasi

\section{Kebijakan}

Baik 95

$95 \quad 50.80$

Kurang Baik

92

49.20

\section{Kepemimpinan}

Baik 163

87.17

Kurang Baik

Ketersediaan Sarana \& Prasarana K3RS

Baik

Tabel 2 menunjukkan bahwa dari tujuh variabel yang termasuk dalam faktor individu, hanya dua variabel saja yang memiliki hubungan yang bermakna secara statistik yaitu variabel jenis kelamin $(p=0,011)$ dan variabel sikap $(p=0,000)$. Berdasarkan nilai PR maka responden berjenis kelamin perempuan 1,29 kali lebih tinggi untuk melaksanakan K3RS yang baik dibanding responden laki-laki serta responden yang memiliki sikap positif terhadap pelaksanaan K3RS 1,88 kali lebih tinggi untuk melaksanakan K3RS yang baik dibandingkan responden yang memiliki sikap negatif. Sedangkan seluruh variabel bebas pada faktor organisasi memiliki hubungan yang bermakna secara statistik yaitu kebijakan $(p=0,000)$, kepemimpinan $\quad(p=0,010), \quad$ serta ketersediaan sarana prasarana K3RS $(\mathrm{p}=0,026)$. Dilihat dari nilai PR maka responden yang memiliki persepsi bahwa kebijakan K3RS telah baik maka 1,71 kali lebih tinggi untuk melaksanakan K3RS yang baik dibandingkan yang kurang baik, responden yang memiliki persepsi bahwa kepemimpinan K3RS telah baik maka 1,15 kali lebih tinggi untuk melaksanakan K3RS yang baik dibandingkan kurang baik, serta responden yang memiliki persepsi bahwa ketersediaan sarana prasarana K3RS telah baik maka 1,12 kali lebih tinggi untuk melaksanakan K3RS yang baik dibandingkan kurang baik.

Tabel 2. Hubungan Bivariabel Pelaksanaan K3RS berdasarkan Faktor Individu dan Organisasi 
Vol. 7 No. $2: 35$ - 47

\begin{tabular}{|c|c|c|c|c|c|}
\hline & $\begin{array}{l}\text { Baik } \\
\text { n (\%) }\end{array}$ & $\begin{array}{c}\text { Kurang Baik } \\
\text { n (\%) }\end{array}$ & n (\%) & & \\
\hline \multicolumn{6}{|c|}{ Faktor Individu } \\
\hline \multicolumn{6}{|c|}{ Umur } \\
\hline$\geq 30$ tahun & $86(53.42)$ & $75(46.58)$ & $161(100)$ & \multirow{2}{*}{0.98} & \multirow{2}{*}{0.967} \\
\hline$<30$ tahun & $14(53.85)$ & $12(46.15)$ & $26(100)$ & & \\
\hline \multicolumn{6}{|c|}{ Jenis Kelamin } \\
\hline Perempuan & $77(59.69)$ & $52(40.31)$ & $129(100)$ & \multirow{2}{*}{1.29} & \multirow{2}{*}{0.011} \\
\hline Laki-laki & $23(39.66)$ & $35(60.34)$ & $58(100)$ & & \\
\hline \multicolumn{6}{|c|}{ Tingkat Pendidikan } \\
\hline Tinggi & $31(48.44)$ & $33(51.56)$ & $64(100)$ & \multirow{2}{*}{0.82} & \multirow{2}{*}{0.319} \\
\hline Menengah & $69(56.10)$ & $54(43.90)$ & $123(100)$ & & \\
\hline \multicolumn{6}{|l|}{ Pekerjaan } \\
\hline Non Medis & $85(55.92)$ & $67(44.08)$ & $152(100)$ & \multirow{2}{*}{1.10} & \multirow{2}{*}{0.162} \\
\hline Medis & $15(42.86)$ & $20(57.14)$ & $35(100)$ & & \\
\hline \multicolumn{6}{|l|}{ Masa Kerja } \\
\hline$\geq 11$ tahun & $55(55.00)$ & $45(45.00)$ & $100(100)$ & \multirow{2}{*}{1.06} & \multirow{2}{*}{0.654} \\
\hline$<11$ tahun & $45(51.72)$ & $42(48.28)$ & $87(100)$ & & \\
\hline \multicolumn{6}{|l|}{ Pengetahuan } \\
\hline Baik & $70(56.00)$ & $55(44.00)$ & $125(100)$ & \multirow{2}{*}{1.11} & \multirow{2}{*}{0.326} \\
\hline Kurang Baik & $30(48.39)$ & $32(51.61)$ & $62(100)$ & & \\
\hline \multicolumn{6}{|l|}{ Sikap } \\
\hline Positif & $67(68.37)$ & $31(31.63)$ & $98(100)$ & \multirow{2}{*}{1.88} & \multirow{2}{*}{0.000} \\
\hline Negatif & $33(37.08)$ & $56(62.92)$ & $89(100)$ & & \\
\hline \multicolumn{6}{|c|}{ Faktor Organisasi } \\
\hline \multicolumn{6}{|c|}{ Kebijakan } \\
\hline Baik & $63(66.32)$ & $32(33.68)$ & $95(100)$ & \multirow{2}{*}{1.71} & \multirow{2}{*}{0.000} \\
\hline Kurang Baik & $37(40.22)$ & $55(59.78)$ & $92(100)$ & & \\
\hline \multicolumn{6}{|c|}{ Kepemimpinan } \\
\hline Baik & $93(57.06)$ & $70(42.52)$ & $163(100)$ & \multirow{2}{*}{1.15} & \multirow{2}{*}{0.010} \\
\hline Kurang Baik & $7(29.17)$ & $17(70.83)$ & $24(100)$ & & \\
\hline Sarana \& I & & & & & \\
\hline K3RS & & & & & \\
\hline Baik & $94(56.48)$ & $73(43.71)$ & $167(100)$ & 111 & 000 \\
\hline Kurang Baik & $6(30.00)$ & $14(70.00)$ & $20(100)$ & 1.12 & 0.026 \\
\hline
\end{tabular}

Hasil analisis multivariabel pada Tabel 3 menunjukkan bahwa variabel yang memiliki hubungan secara bersama- sama dengan pelaksanaan K3RS adalah variabel sikap dan kebijakan, dimana 
Arc. Com. Health • Desember 2020

faktor yang paling dominan berhubungan dengan pelaksanaan K3RS adalah sikap setelah dikontrol oleh variabel kebijakan. Jika dilihat dari nilai adjusted PR maka responden yang memiliki sikap positif

Tabel 3. Analisis Multivariabel Pelaksanaan K3RS terhadap K3RS maka 1.59 kali lebih tinggi untuk melaksanakan K3RS dengan baik dibandingkan dengan responden yang memiliki sikap negatif terhadap K3RS.

\begin{tabular}{lcccc}
\hline \multirow{2}{*}{ Variabel } & & & \multicolumn{2}{c}{$\begin{array}{c}\text { Model Akhir } \\
\mathbf{9 5 \%} \text { CI for Adjusted PR }\end{array}$} \\
\hline Sikap Positif & $\mathbf{p}$ & Adjusted PR & Lower & Upper \\
\hline Kebijakan Baik & 0.012 & 1.59 & 1.11 & 2.30 \\
\hline
\end{tabular}

\section{DISKUSI}

Berdasarkan analisis multivariabel, diketahui bahwa variabel umur, jenis kelamin, tingkat pendidikan, pekerjaan, masa kerja, pengetahuan, kepemimpinan serta ketersediaan sarana dan prasarana tidak berhubungan signifikan secara bersama-sama dengan pelaksanaan K3RS. Namun variabel yang memiliki hubungan signifikan secara bersama-sama dengan pelaksanaan K3RS adalah sikap dan kebijakan.

Variabel sikap merupakan faktor yang paling dominan berhubungan dengan pelaksanaan K3RS, yang mana responden yang memiliki sikap positif terhadap pelaksanaan K3RS maka 1.59 kali lebih tinggi memiliki pelaksanaan K3RS baik dibandingkan dengan responden yang memiliki sikap negatif terhadap pelaksanaan K3RS ( $\mathrm{PR}=1,59$; 95\%CI:1,11-2.30; $\mathrm{p}=0,012)$. Hasil penelitian ini didukung oleh penelitian Putri dkk (2018) yang menyatakan bahwa sikap merupakan variabel yang paling dominan berhubungan dengan kecelakaan kerja pada perawat rumah sakit, dimana perawat yang memiliki sikap negatif berisiko 22 kali mengalami kejadian kecelakaan kerja dibandingkan dengan perawat yang bersikap positif $(\mathrm{OR}=22,392$; 95\%CI:4,091-122,599; $\quad \mathrm{p}=0,001) . \quad$ Pada penelitian Winarno (2016), walaupun bukan sebagai faktor yang paling dominan, namun sikap memiliki pengaruh terhadap pelaksanaan $\mathrm{K} 3$ di RSU Mitra Medika Medan dimana setiap peningkatan sikap petugas pelaksana akan mengakibatkan peningkatan penerapan K3 sebesar 0,108. Hasil penelitian ini juga sejalan dengan penelitian Marchamah \& Woro (2017), yang menyimpulkan bahwa terdapat pengaruh yang signifikan antara sikap K3 terhadap penggunaan APD pada tenaga bongkar muat. Pada penelitian ini distribusi jawaban sikap dan jawaban pelaksanaan K3RS sejalan, yang mana responden sangat memperhatikan penggunaan APD, serta berhati-hati dalam pekerjaan yang berisiko seperti 
Vol. 7 No. $2: 35$ - 47

penggunaan B3. Sehingga diharapkan pihak rumah sakit memperhatikan ketersediaan APD bagi SDM rumah sakit.

Kebijakan memiliki hubungan yang bermakna secara statistik dengan pelaksanaan K3RS $(p<0,05)$, yang mana responden yang memiliki persepsi bahwa kebijakan K3RS telah baik maka 1,41 kali lebih tinggi untuk memiliki pelaksanaan K3RS baik dibandingkan dengan responden yang memiliki persepsi bahwa kebijakan K3RS kurang baik. Hasil penelitian serupa ditemukan juga pada penelitian Winarno (2016), yang menyatakan bahwa variabel kebijakan berhubungan dengan penerapan K3RS $(p<0,05)$. Hasil penelitian ini juga sejalan dengan penelitian Yuniarti (2006) yang menyatakan bahwa ada hubungan kebijakan K3 dengan KAK pada pekerja di PT. Indo Bharat Rayon Purwakarta. Namun hasil ini bertolak belakang dengan hasil penelitian Marchamah \& Woro (2017), yang menyimpulkan bahwa tidak terdapat pengaruh yang signifikan antara komitmen kebijakan terhadap penggunaan APD yang merupakan salah satu indikator pelaksanaan $\mathrm{K} 3(\mathrm{p}=0,223)$. Adanya perbedaan hasil penelitian ini disebabkan kebijakan yang dimiliki oleh masing-masing organisasi berbeda-beda. Berdasarkan hasil wawancara, rumah sakit telah memiliki kebijakan terkait K3RS yang telah didokumentasikan dan dikomunikasikan kepada seluruh SDM rumah sakit, karena pimpinan rumah sakit sadar bahwa kebijakan K3RS menjadi landasan utama yang diharapkan mampu menggerakkan semua elemen di dalam rumah sakit sehingga dapat terwujudnya pelaksanaan K3RS yang baik. Namun berdasarkan pernyataan responden, penyusunan K3RS belum melibatkan seluruh elemen rumah sakit.

Berdasarkan hasil tersebut, maka sikap dan kebijakan dapat dijadikan sebagai tolak ukur untuk meningkatkan pelaksanaan K3RS. Selain itu, karena indikator yang diukur pada variabel sikap juga terkait dengan kebijakan K3RS, kepemimpinan K3RS serta ketersediaan sarana dan prasarana K3RS sehingga untuk meningkatkan pelaksanaan K3RS yang baik maka kebijakan K3RS perlu disusun dengan melibatkan seluruh petugas rumah sakit sehingga sesuai dengan kondisi yang dihadapi serta kebijakan K3RS yang telah disusun dikomunikasikan ke seluruh petugas rumah sakit. Peran pemimpin rumah sakit serta kepala unit/bagian kerja juga sangat penting dalam memberikan arahan/bimbingan dan menjadi contoh dalam melaksanakan K3RS yang baik serta menyediakan sarana dan prasaran K3RS yang menunjang pelaksanaan K3RS.

Pada penelitian ini, faktor individu yang tidak berhubungan signifikan secara bersama-sama dengan pelaksanaan K3RS adalah umur, jenis kelamin, tingkat pendidikan, pekerjaan, masa kerja serta pengetahuan. Umur tidak berhubungan signifikan dengan pelaksanaan K3RS. Hasil penelitian ini sesuai dengan penelitian Rahayu (2015), yaitu tidak terdapat hubungan yang bermakna antara umur dengan penerapan manajemen budaya K3 ( $>>0,05)$ karena pekerja dengan umur di atas rata-rata dan di bawah ratarata sebagian besar telah menerapkan 
budaya K3 dengan baik sehingga umur diinterpretasikan tidak berpengaruh terhadap manajemen budaya K3 tetapi tergantung pendewasaan diri seseorang.

Hasil analisis bivariabel pada variabel jenis kelamin dengan pelaksanaan K3RS menunjukkan bahwa adanya hubungan yang bermakna secara statistik $(p=0,011)$. Hasil penelitian ini serupa dengan hasil penelitian Arini (2016), bahwa terdapat perbedaan yang bermakna dalam hal kepatuhan hand hygiene $(\mathrm{p}=0,035)$ yang merupakan salah satu indikator pelaksanaan K3RS berdasarkan jenis kelamin yang mana wanita memiliki kepatuhan lebih tinggi. Namun berdasarkan hasil analisis multivariabel, jenis kelamin tidak memiliki hubungan yang signifikan dengan pelaksanaan K3RS.

Berdasarkan analisis bivariabel dan multivariabel, variabel tingkat pendidikan pada penelitian ini tidak memiliki hubungan yang bermakna secara statistik dengan pelaksanaan K3RS $(p>0,05)$. Hasil serupa ditemukan pada penelitian Rahayu (2015), bahwa pendidikan tidak berpengaruh terhadap penerapan budaya $\mathrm{K} 3(\mathrm{p}=0,204)$ serta pada penelitian Imania (2010), dimana tingkat pengetahuan juga tidak memiliki hubungan yang bermakna secara statistik dengan perilaku K3 perawat $(p=1,00)$. Namun pada penelitian Kurniawan, dkk (2006) diperoleh hasil yang berbeda, yaitu terdapat hubungan antara tingkat pendidikan pekerja dengan praktik penerapan prosedur keselamatan kerja $(p=0,001)$ dimana hubungan tersebut bersifat positif dan berkorelasi cukup kuat (koefisien korelasi=0,519), yang mana disimpulkan bahwa semakin tinggi pendidikan formal seseorang maka semakin baik pemahaman tentang prosedur keselamatan kerja sehingga memiliki praktik K3 yang baik, akan tetapi pada penelitian ini pelaksanaan K3RS yang baik lebih banyak ditemukan pada kelompok responden dengan tingkat pendidikan menengah dibanding responden dengan tingkat pendidikan tinggi. Hal tersebut kemungkinan disebabkan karena pada saat wawancara ada beberapa responden diberitahukan jawaban oleh rekan kerjanya sehingga menyebabkan responden yang memiliki pendidikan menengah lebih banyak memiliki pelaksanaan K3RS yang baik daripada responden yang memiliki pendidikan tinggi.

Hasil analisis bivariabel dan multivariabel menunjukkan tidak terdapat hubungan yang bermakna antara variabel pekerjaan dengan pelaksanaan K3RS $(p=0,162)$. Tidak adanya hubungan antara pekerjaan dengan pelaksanaan K3RS ini didukung oleh teori dari Notoatmodjo (2007) yang menyatakan bahwa pekerjaan merupakan salah satu bagian dari faktor sosial yang bersifat dinamis. Suatu lingkungan sosial tertentu tidak begitu saja memberi pengaruh yang sama kepada setiap orang, akan tetapi kebiasaan sosial akan memberikan pengaruh terhadap kesehatan.

Pada variabel masa kerja dengan pelaksanaan K3RS didapatkan hasil bahwa tidak terdapat hubungan yang 
bermakna secara statistik $(p=0.654)$ berdasarkan analisis bivariabel maupun multivariabel. Hasil penelitian serupa ditemukan pada penelitian Kurniawan dkk (2006), bahwa tidak ada hubungan antara masa kerja dengan praktik penerapan prosedur keselamatan kerja dengan nilai $p=0,087$. Namun hasil yang berbeda ditemukan pada penelitian Imania (2010), dimana terdapat hubungan yang bermakna antara masa kerja dengan perilaku K3 perawat $(\mathrm{p}=0,040)$. Nazirah \& Yuswardi (2017) juga menyatakan bahwa semakin lama masa kerja perawat maka pengalaman yang dimiliki juga semakin meningkat sehingga perilaku dalam menjaga keselamatan dirinya juga semakin membaik, akan tetapi pada penelitian ini tidak terdapat perbedaan proporsi yang signifikan pada pelaksanaan K3RS yang baik antara responden dengan masa kerja $<11$ tahun ataupun responden dengan masa kerja $\geq 11$ tahun. Tidak terdapat perbedaan proporsi ini dapat disebabkan karena setiap pegawai baru telah diberikan pelatihan K3RS sehingga pemahaman terhadap prosedur kerja yang aman telah dimiliki melalui pelatihan sejak awal bekerja.

Pengetahuan pada penelitian ini tidak memiliki hubungan yang signifikan dengan pelaksanaan K3RS baik pada analisis bivariabel maupun multivariabel. Hasil penelitian serupa ditemukan pada penelitian Ernawati \& Nurlelawati (2017), bahwa tidak ada hubungan yang bermakna antara pengetahuan terhadap penerapan K3 di RSIA Permata Sarana Husada periode Februari 2015 ( $p=0,196)$. Namun, berbeda dengan hasil penelitian
Durduran dkk (2018) mengenai praktik keselamatan dan kesehatan kerja pada pekerja rumah sakit, diketahui bahwa terdapat hubungan bermakna $(p<0,05)$ antara pengetahuan dengan praktik keselamatan dan kesehatan kerja pada pekerja rumah sakit.

Faktor organisasi yang tidak berhubungan signifikan dengan pelaksanaan K3RS adalah kepemimpinan serta ketersediaan sarana dan prasarana K3RS. Pada analisis bivariabel, variabel kepemimpinan memiliki hubungan yang signifikan dengan pelaksanaan K3RS $(p<0,05)$, namun setelah dianalisis multivariabel tidak berhubungan signifikan dengan pelaksanaan K3RS. Hasil berbeda ditemukan pada penelitian Winarno (2016) yang menyatakan bahwa terdapat pengaruh yang signifikan antara kepemimpinan terhadap penerapan $\mathrm{K} 3$ di RSU Mitra Medika Medan $(p<0,05)$ serta pada penelitian Aprillia \& Apriatni (2016) juga menyatakan bahwa kepemimpinan berpengaruh positif dan signifikan terhadap kinerja karyawan.

Ketersediaan sarana dan prasarana K3RS tidak berhubungan signifikan dengan pelaksanaan K3RS. Hasil penelitian berbeda ditemukan pada penelitian Ernawati \& Nurlelawati (2017) yang menyatakan bahwa sarana dan prasarana K3RS seperti APD memiliki hubungan dengan pelaksanaan penerapan K3 pada tenaga kesehatan di RSIA Permata Sarana Husada ( $p=0,001)$. Menurut penelitian Sinaga (2015) juga terdapat hubungan yang bermakna antara ketersediaan sarana dengan kepatuhan melakukan hand hygiene $(\mathrm{p}=0,000)$ yang 
merupakan salah satu pelaksanaan K3RS pada tenaga kesehatan di RS Misi Rangkasbitung.

Adapun kelemahan penelitian dalam hal pelaksanaan maupun hasil yaitu pada variabel pelaksanaan K3RS, pengukuran hanya berdasarkan hasil kuesioner tanpa melakukan observasi langsung. Hal ini dapat menyebabkan ketidaksesuaian data dengan kenyataan yang dilakukan oleh responden di lapangan, kurangnya referensi penelitian dengan topik K3RS serta kecenderungan responden menjawab pertanyaan atau pernyataan yang cenderung mengarah ke jawaban positif.

\section{SIMPULAN}

Berdasarkan hasil penelitian yang telah dilakukan, maka ditarik kesimpulan bahwa sebanyak 53,48\% responden memiliki pelaksanaan K3RS yang baik. Hasil uji chi-square menunjukkan bahwa faktor individu yang meliputi jenis kelamin dan sikap serta faktor organisasi meliputi kebijakan, kepemimpinan dan ketersediaan sarana dan prasarana memiliki hubungan yang bermakna terhadap pelaksanaan K3RS $(p<0,05)$. Berdasarkan analisis multivariabel, variabel sikap dan kebijakan secara bersama-sama memiliki hubungan yang bermakna terhadap pelaksanaan K3RS, dimana faktor individu berupa sikap merupakan faktor yang paling dominan berhubungan dengan pelaksanaan K3RS.

\section{SARAN}

Bagi pihak rumah sakit diharapkan melibatkan seluruh petugas rumah sakit dalam penyusunan kebijakan K3RS sehingga kebijakan yang disusun sesuai dengan situasi dan kondisi yang terdapat di rumah sakit serta kebijakan K3RS lebih dikomunikasikan kepada seluruh SDM rumah sakit misalkan melalui rapat intern setiap bagian/unit kerja sehingga acuan dalam melakukan pekerjaan dapat berlandaskan atas K3. Selain itu pemimpin rumah sakit serta kepala unit/bagian kerja juga diharapkan dapat memberikan arahan/bimbingan dan menjadi contoh dalam melaksanakan K3RS yang baik serta menyediakan sarana dan prasarana K3RS yang menunjang pelaksanaan K3RS.

Bagi tenaga kesehatan diharapkan semakin meningkatan kesadaran dalam bekerja sesuai SOP dan selalu berhati-hati saat bekerja terutama menggunakan benda tajam dan bahan B3 sehingga resiko untuk terjadinya kecelakaan kerja dapat berkurang, saling mengingatkan kepada rekan kerja pentingnya pelaksanaan $\mathrm{K} 3$ serta melaporkan kepada pihak rumah sakit apabila terdapat kejadian kecelakaan kerja atau hampir celaka (nearmiss) serta melaporkan kepada pihak yang berwenang apabila terdapat kondisikondisi yang dapat membahayakan setiap orang yang ada di dalam rumah sakit.

Bagi peneliti lain yang ingin mengambil topik serupa dapat melakukan observasi langsung terhadap pelaksanaan K3RS yang dilakukan oleh responden serta melakukan observasi terhadap ketersediaan sarana dan prasarana K3RS agar dapat menyesuaikan jawaban dari responden dengan keadaan yang sebenarnya. 
Vol. 7 No. $2: 35$ - 47

\section{DAFTAR PUSTAKA}

Aprillia, R., \& Apriatni, E.P. (2016). Pengaruh Kepemimpinan dan K3 terhadap Kinerja Karyawan Bagian Teknik PT. PLN (Persero) UPJSemarang. Jurnal Administrasi Bisnis, 5(1): 1-5

Arini, M. (2016). Health Belief Model pada Kepatuhan Hand Hygiene di Bangsal Berisiko Tinggi Healthcare Acquired Infections (HAIs) (Studi Kasus pada Rumah Sakit X). Jurnal Medicoeticolegal dan Manajemen Rumah Sakit, 5 (2): 129-135

Durduran, Y., Ay, M., Demir, L.S., Uyar, M., Kayapinar, O., Ozdemir, M., Boyraz, Y.K., \& Sahin, T.K. (2018). The Factors Affecting the Occupational Health-Safety Practice of the Hospital Workers with Knowledge-Attention Status. Saudi Journal of Biomedical Research, 3 (4): 151-155.

Ernawati, N., \& Nurlelawati, E. (2017). Faktor-faktor yang Berhubungan dengan Pelaksanaan Penerapan K3 pada Tenaga Kesehatan di RSIA Permata Sarana Husada Periode Februari 2015. Jurnal Akademi Keperawatan Husada Karya Jaya, 3 (1).

Imania, L. (2010). Hubungan antara Karakteristik Individu dengan Perilaku K3 pada Perawat Instalasi Gawat Darurat Rumah Sakit Umum Haji Surabaya. Skripsi: Universitas Airlangga.

Kurniawan, B., Lestantyo, D., \& Murtiningsih, D. (2006). Hubungan
Karakteristik Pekerja dengan Praktik Penerapan Prosedur Keselamatan Kerja di PT. Bina Buna Kimia Ungaran. Jurnal Promosi Kesehatan Indonesia, 1 (2): 94-104.

Kementerian Kesehatan RI. (2010). Keputusan Menteri Kesehatan Republik Indonesia Nomor: 1087/MENKES/SK/VIII/2010 tentang Standar Kesehatan dan Keselamatan Kerja di Rumah Sakit. Jakarta.

Kementerian Kesehatan RI. (2016). Peraturan Menteri Kesehatan Republik Indonesia Nomor 66 Tahun 2016 tentang Keselamatan dan Kesehatan Kerja Rumah Sakit. Jakarta.

Marchamah, D. N. S., \& Woro, O. (2017). Komitmen Kebijakan, Penerapan SMK3, Pengetahuan, dan Sikap K3 terhadap Penggunaan APD Perusahaan Jasa Bongkar Muat. Public Health Perspective Journal, 2(3): 270-278.

Nazirah, R., \& Yuswardi. (2017). Perilaku Perawat dalam Penerapan Manajemen Kesehatan dan Keselamatan Kerja (K3) di Aceh. Idea Nursing Journal, 8 (3): 20872879 .

Notoatmodjo, S. (2007). Kesehatan Masyarakat Ilmu \& Seni. Jakarta: PT Rineka Cipta

Occupational Safety and Health Administration (OSHA). (2013). Fact About Hospital Worker Safety. 
United State of America. [Accessed: January 20, 2019] Available at: https://www.osha.gov/dsg/hospital s/documents/1.2 Factbook 508.pdf

Putri, S., Rahayu, E.P., \& Santoso. (2018) Pelaksanaan Keselamatan dan Kesehatan Kerja terhadap Kejadian Kecelakaan Kerja Perawat Rumah Sakit. Jurnal Endurance, 3 (2): 271277.

Rahayu, E.P. (2015). Hubungan antara Pengetahuan, Sikap, dan Perilaku Karyawan dengan Penerapan Manajemen Budaya Keselamatan dan Kesehatan Kerja di Bagian Produksi PT. Mustika Ratu. Jurnal Kesehatan Komunitas, 2 (6): 289-293.

Ristiono, B., \& Azkha, N. (2010). Regulasi dan Penerapan Keselamatan dan Kesehatan Kerja (K3) Rumah Sakit di Propinsi Sumatera Utara. Jurnal Kesehatan Masyarakat, 4 (1): 53-59.

Widarsa, T. Putra, A.E., \& Astuti A.S. (2016). Analisis Data untuk Variabel Binary Outcome. Program Studi Kesehatan Masyarakat. Fakultas Kedokteran Universitas Udayana.

Winarno, E. (2016). Faktor-Faktor yang Memengaruhi Penerapan K3 di Rumah Sakit Umum Mitra Medika Medan Tahun 2016. Tesis. Fakultas Kesehatan Masyarakat: Universitas Sumatera Utara.

Yuniarti, R. (2006). Analisis Faktor-faktor yang Berhubungan dengan Kecelakaan Kerja di PT. Indo Bharat Rayon Purwakarta Tahun 2006. Skripsi.
Fakultas Kesehatan Masyarakat: Universitas Indonesia. Depok 